XXIII SEMINÁRIO DE INICIAÇÃO CIENTÍFICA DA UEFS SEMANA NACIONAL DE CIENTÍFICA E TECNOLÓGICA - 2019

\title{
ESTUDO ANALÍTICO DAS CONCEPÇÕES DE FORMAÇÃO DE PROFESSORES-FORMADORES EM CONTRASTE COM A CONCEPÇÃO DE LICENCIADOS EGRESSOS DA LICENCIATURA EM EDUCAÇÃO FÍSICA
}

\author{
$\underline{\text { Janyelle Costa da Circuncisão }}^{1}$; Ana Verena Freitas Paim² \\ 1.Bolsista PROBIC/UEFS, Graduando em licenciatura em Educação Física, Universidade Estadual de Feira \\ de Santana, e-mail: janyelle_500@ hotmail.com \\ 2.Orientador, Departamento de Educação, Universidade Estadual de Feira de Santana, e-mail: \\ verenaebranca@gmail.com
}

PALAVRAS-CHAVE: concepção de formação, licenciado, professor-formador.

\section{INTRODUÇÃO}

Este estudo vincula-se à pesquisa intitulada Tal formação, tal ensino? Uma (re) leitura das políticas de sentido do ensino de professores-formadores, como atos de currículo, que podem qualificar a formação do licenciado e suas práticas docentes em sala de aula, desenvolvido junto ao Grupo de Estudos e Pesquisas em Currículo e Formação do Ser em Aprendizagens - FORMARSER, da Universidade Estadual de Feira de Santana (UEFS) - Bahia, que possui como objetivo principal compreender como as políticas de sentido do ensino de professores formadores, enquanto atos de currículo podem qualificar a formação do licenciado e sua prática docente.

O propósito do estudo em pauta, é compreender as políticas de sentido sobre ensino e formação, junto aos professores-formadores e egressos, do curso de Licenciatura em Educação Física da UEFS, por meio de uma análise contrastiva entre suas concepções de formação, com o objetivo de entender, em que medida as concepções dos professoresformadores pesam ou influenciam na prática dos licenciados que estão atuando na educação básica, para tal compreensão iremos ao encontro dos licenciados e dos formadores.

Compreendendo que nossa investigação tem como foco o ensino dentro do nível superior, realçamos que:

[...] o professor universitário aparece como o agente produtor de saberes, responsável pelo reencaminhamento no que diz respeito à formação de gerações, à construção da identidade e profissionalização docente do futuro professor da Educação Básica. (KRUGER; KRUG, 2009, p. 53) 
Durante o processo de sua formação, os licenciandos vão construindo e desenvolvendo sua concepção de formação, a qual esta que implicará no seu fazer docente. Tal concepção é arquitetada a partir de um agregado de referências, experiências e tudo que observou, percebeu, filtrou para si, vivenciou, dentro da universidade, seu histórico de vida e suas visões também contribuem para essa construção. Como afirma Bellochio (2003, p.17), "a concepção de formação, de forma histórica, está intrinsecamente relacionada com o perfil do egresso do sistema formador e suas possibilidades de atuação profissional [...]". Neste sentido, a prática pedagógica do egresso pode traduzir uma concepção de formação e ensino, cuja origem reside nas experiências formativas vividas, no contexto da licenciatura.

Se referindo à formação do curso de Licenciatura em Educação Física, de acordo com Kruger (2007, p. 21-22), ele visa formar:

[...] professores para atuar na educação básica no sentido de: desenvolver ações, teórico-práticas em que os conhecimentos e saberes acadêmicos contribuam na formação do ser humano em sua totalidade, possibilitar uma formação político-social, dentro de uma abordagem histórico-crítica, em diferentes manifestações da cultura corporal, compromissada com a educação emancipatória, possibilitar uma formação técnicoprofissional visando o aperfeiçoamento de habilidades, capacidades e competências necessária ao exercício profissional/docente.

Diante das considerações, percebemos que é na formação inicial que os licenciados, constroem, com mais sentido e significado seu perfil de formação, assim como suas concepções e é partir disso que irá exercer sua prática profissional futura. Assim, os processos existentes no âmbito da licenciatura estão diretamente correlacionados e de modo geral influi na prática do egresso.

\section{MATERIAL E METODOLOGIA}

A metodologia adotada nessa investigação é de natureza qualitativa, com opção teórico-metodológica da etnopesquisa crítica e multirreferencial e da etnossociologia, posto que nas duas vertentes de pesquisa, o pesquisador vai ao encontro dos sujeitos participantes no local em que eles atuam.

No caso específico do Plano de Trabalho, nos propusemos a ir ao encontro dos participantes egressos da licenciatura em Educação Física da UEFS e de seus professoresformadores, no seu ambiente de trabalho, para dialogar sobre questões referentes ao ensino e a formação docente, objetos centrais da pesquisa, a qual o presente estudo está ancorado. Para tanto, fizemos uso de entrevista semi-estruturada, no intuito de obter informações sobre os aspectos em pauta.

Previamente, elaboramos dois roteiros para o momento da entrevista, um para o licenciado e outro para o formador. Tivemos oito colaboradores, sendo quatro de cada grupo. A primeira parte da investigação foi realizada com os egressos, de quatro escolas diferentes, e a segunda parte, com os formadores.

Inicialmente, para as ações dessa investigação, escolhemos as escolas-campo, sendo estas da rede pública de ensino da educação básica da cidade de Feira de Santana. A partir daí apresentamos a nossa proposta nas escolas, aos professores de Educação 
Física egressos da UEFS que aderiram e optaram por participar. Mantivemos então contato prévio e marcamos um momento de acordo a sua disponibilidade para realização da entrevista. Uma vez realizadas as entrevistas com os egressos, fizemos o mesmo procedimento com os professores-formadores.

Com todas as narrativas coletadas, seu conteúdo foi transcrito, analisado e tensionado com nossos objetivos e as bases teóricas que inspiram o estudo, assim fazendo um contraste entre as informações fornecidas pelos formadores e licenciados egressos.

\section{RESULTADOS E DISCUSSÃO}

Através das narrativas dos egressos do Curso de Licenciatura em Educação Física, obtemos informações referentes a concepção de ensino, a relação entre esta com as experiências de formação na universidade e como as influencia no desenvolvimento de suas práticas de ensino. A partir das transcrições das entrevistas dos professoresformadores, fizemos um contraste entre os dados obtidos, o que nos permitiu analisar nossa problemática investigativa.

Verificamos que os licenciados egressos atribuem relevância às aprendizagens construídas no contexto do curso de licenciatura em Educação Física por meio do ensino de seus professores-formadores, mas não deixam de pontuar a maior fragilidade que é o distanciamento das práticas de formação às da educação básica e, por conseguinte, de situações que contribuam para o licenciando atuar diretamente nas atividades próprias de sua área de conhecimento dentro das escolas da rede de ensino, seja público ou privado. E nesse sentido, programas como o PIBID e Residência Pedagógica foram bastante realçados enquanto possibilidades fecundas de formação pautada nas situações práticas da docência.

\section{CONSIDERAÇÕES FINAIS}

A partir das nossas investigações e de todas as atividades desenvolvidas durante o processo de pesquisa, podemos concluir que as políticas de sentido do ensino dos professores-formadores, enquanto atos de currículo, qualificam a formação do licenciado e sua prática docente, contribuindo significativamente na sua atuação. Dialogando com autores do campo da formação docente, analisando os dados coletados a partir das entrevistas, concluímos que há uma forte correlação das práticas formativas das licenciaturas e as práticas desenvolvidas pelos licenciados, no contexto das escolas públicas da rede básica.

Desse modo, confirmamos nossa hipótese de que o modelo de formação vigente dentro do curso de licenciatura da UEFS, é subsídio para o desenvolvimento da prática pedagógica dos egressos atuantes na educação básica. Estudos posteriores, sobre a mesma problemática ampliariam as considerações alcançadas.

Face ao exposto, afirmamos que formação e ensino, no âmbito da licenciatura, são processos correlacionados, que interferem na constituição das práticas dos futuros profissionais docentes. Portanto, é imprescindível que essas pautas façam parte das discussões no contexto da universidade e nas instâncias colegiadas dos cursos de licenciatura a fim de que possamos qualificar de maneira ascendente a formação de professores, considerando para tanto, as demandas e desafios sociais, políticos, culturais e pedagógicos dos tempos atuais. 


\section{REFERÊNCIAS}

KRUGER, L. G. et al. As concepções da formação profissional da licenciatura em Educação Física: trajetórias docentes e suas perspectivas contributivas. 2007. Disponível em:

$<$ https://repositorio.ufsm.br/bitstream/handle/1/7257/leonardo.pdf?sequence=1\&isAllo wed $=\mathrm{y}>$. Acesso em: 29 jul. 2019.

KRUGER, L. G.; KRUG, H. N.. Licenciatura em Educação Física: concepções a partir da vivência experienciada dos professores do ensino superior em seu percurso formativo.

Movimento, v. 15, n. 1, 2009. 